Journal Universitas Muhammadiyah Gresik Engineering, Social Science, and Health International Conference (UMGESHIC)

UMGCINMATIC : $1^{\text {st }}$ Rethinking Education during Covid-19 Era: Challange and Innovation

\title{
THE INFLUENCE OF THE LEVEL COMMUNITY INVOLVEMENT WITH SUCCESS LEVEL OF IMPLEMENTING PROGRAM CSR (CORPORATE SOCIAL RESPONSIBILITY)
}

\author{
Author \\ Nanda Ayu Pratiwi 1, Awang S. Wicaksono 2 , Ima Fitri Sholicha 3 \\ Faculty of Psychology, Universitas Muhammadiyah Gresik \\ nandaayupratiwi25@gmail.com, awangwicaksono.psi@umg.ac.id \\ 2,Ima_fitri@umg.ac.id ${ }^{3}$,
}

\begin{abstract}
Community involvement is very important for the success of a CSR program, therefore the community should be involved in the implementation of the CSR program so that the CSR program provided can achieve success, so that the community can benefit from the results of the CSR program. To find out empirically the influence of the level of community involvement with the success rate of CSR program implementation. The research using a quantitative research and incidental sampling technique. The total population of active people who participate in the management of the CSR program is 79 people and a sample of 79 people who are active in the program implementation. The data analysis technique used simple linear regression test analysis. It can be concluded that there is a significant influence between the level of community involvement and the success rate of implementing the CSR program, so that the higher the level of community involvement, the higher the success rate of program implementation. With the CSR program, the community becomes prosperous and feels comfortable because the company has a negative impact, namely disturbing the surrounding environment due to waste or pollution. Not all communities become research subjects. For further researchers, they should get more attention to the surrounding environment and companies that have an interest in CSR programs.
\end{abstract}

Keywords :CommunityInvolvement, Successful Implementation of CSR Programs. 


\section{INTRODUCTION}

CSR (Corporate Social Responsibility) or commonly called corporate social responsibility is a concept of an organization, especially corporate organizations are having variousresponsibilities to all stakeholders, including consumers, employees, shareholders, communities and the environment in all aspects of company operations that are as a whole related to, social and environmental aspects. CSR is a commitment of a company to improve the welfare of the community through good business practicality and cooperation with some of the company\&\#39;s resources. [1] CSR (Corporate Social Responsibility) can be said to be the role of the company to sustainable goals if the organization or company in carrying out its activities must be based on a decision, so that it is not solely based on its impact in economic aspects, for example the level of profit or dividends but must also consider the social and environmental impact that arises from its decision, where it can be for the long term or the long term. short. CSR(Corporate Social Responsibility) is a growing discussion in the business or corporate world. This discussion is used for companies in order to take the role of facing the economy towards the free market. The development of free markets that have become the bonds of the world economy with the formation of AFTA, APEC, etc. This has all encouraged companies from all over the world to compete to give good by jointly doing their activities in the welfare of the surrounding

community. [2] The company conducting this CSR program has a purpose, that csr purpose is, first, because the company is part of the community and therefore it should be the company to pay attention to the interests of the community, this social activity as compensation or reciprocal efforts for the mastery of natural resources (SDA) or economic resources by the company, in addition to the inconvenience to the community. Second, to get support from the community and at least permission to carry out operations of a cultural nature. Third, to reduce or even avoidsocial conflicts, because conflict arises from the operational impact of the company or due to structural and economic gaps that arise between society and company components. [3]

In addition to having a purpose, CSR also has various benefits, namely the first, benefits for individual employees, CSR can be used as an alternative learning method in doing business, facing skills development challenges and can acquire new skills, increase company knowledge about the community, and obtain new perceptions of the business being implemented. Second, the benefits for CSR program recipients can be used to acquire skills and skills that the organization does not already have or do not have the funds to do so, can get creative skills in solving various problems, and who certainly gain experience from large organizations. The third benefit, namely the benefits for the company itself can be used to improve the capabilities of employees who have completed community work tasks, get opportunities to provide practical assistance to the community, increase knowledge about the local community, can improve the company\&\#39; s image and profile. Of all these benefits it is seen that the realization of CSR to the surrounding community can be implemented by making various programs in the form of community development. [4]

In Indonesia, the understanding of CSR has entered the stage of growth, both conceptually and practically. This shows that the longer indonesians are smarter to accept and interpret CSR as one of the survival supporters. The implementation of CSR in Indonesia has been regulated by the government in the Law of the Republic of Indonesia No. 40 of 2007 concerning Limited Liability 
Companies. In article 74 paragraph 1 it is explained that companies that conduct their business activities in the field and or related to natural resources are obliged to carry out social and environmental responsibilities. In this article has made Indonesia as the country that first requires CSR programs in this world. [3]

The results of research conducted by [5] show that research on CSR programs is very new to the community and has a positive impact on the social condition of the community, it is explained based on the results of interviews from informants. In this research it is explained that every success of the program or activity carried out must be seen from the side of its acceptance not in terms of its giving, so that is interpreted from the acceptance side that is where the community can receive and can take advantage of CSR programs from companies, the community can accept if indeed the community really needs csr programs provided by the company, if the community needs csr then the community will really manage and participate. In the CSR program. If you look at the provision of the program and if the company does not understand and know how the state of society and what should be needed by the community, then the CSR program provided will not be effective and may run only for a short time, and the program can run continuously if the company conducts socialization to the community about theCSR program provided. In this research, the company provided 6 CSR programs to the community, csr programs provided are about education, health, employment, and institutional strengthening through handling malnourished toddlers, scholarships, and environmental conditions in the form of the availability of clean water and air conditions. Not all programs run successfully, there are still found fostered partners who are not better. This happens because other factors that can not be reached by CSR programs in the company, and indeed must be needed a broad study of the situation of the surrounding community, and also needed socialization to the community. [5]

The researcher conducted an initial interview with one of the community administrators, namely the village secretary who manages the CSR program in Kelurahan I in Gresik Regency. Based on the results of interviews about how the CSR program in Kelurahan I was, the village secretary stated that there were many CSR programs provided by company X, with many of these programs covering infrastructure development programs, human resources, health, education, automatically the community would have to participate. and work together in carrying out the program, in kelurahan I community involvement tends to be a development priority, according to the village secretary, so far the CSR program has always been carried out

well and stable from year to year, because indeed the CSR program provided by the company is a program that has been proposed by the community by submitting a proposal to the company, and the program was proposed because the community really needed it, so that made the community involved so that the program could be implemented and could achieve a success. In the provision of CSR programs, there are also obstacles experienced by the management of the CSR program in output I, namely constraints on public understanding of the provision of CSR, the community often misunderstands how to provide CSR, the community considers that the CSR program provided regarding the scope of education is only for an institution is not only for the community, but the community does not realize that an educational institution will also

return to the community for their children to go to school. This means that the community 
wants the CSR program provided to be in a tangible form or form that is visible in front of them. But from year to year until now, the community finally understands the benefits and objectives of the CSR program with the help of explanations and understanding from the CSR program management in the village.

Corporate Social Responsibility is defined as Community Development,one of the principles of Community Developement is engagement. Therefore involvement in community development must result in active involvement for everyone in the community in a process of communityactivities. They realize that by involving the community in every stage of the implementation of CSR program activities, the goal to empower the community to be independent will be successful and the programs implemented will be sustainable. (6)

\section{THEORETICAL FRAMEWORK}

a. Successful Implementation of Corporate Social Responsibility Program

Corporatesocial responsibility (CSR) is a commitment to improving people\&\#39;s well being,general business practices and the contribution of corporate resources. Another definition of corporate social responsibility (CSR) is about how companies manage business processes to generate an overall positive impact on society. [7]

\section{a) Aspects of Measuring the Success Rate of Corporate Social Responsibility Program Implementation}

[8] There are five aspects to measuring the success rate of a program:

\section{Effectiveness(efectivity)}

The success of a company program with its interrelationship in dealing with problems in the community.

2. Conformity(relevance)

Conformity and compatibility between programs carried out according to the needs that really exist in the community.

3. sustainability(sustainability)

Continuing the implementation of programs that can be continuously sustainable.

\section{Empowerment(empowerment)}

The expertise of a program in terms of improving the expertise or empowerment of the community

\section{Participation}

Community participation in the implementation of the program, both in the process of planning, implementation, and guidance and evaluation, as well as related to enjoying the results, it all requires community involvement. 


\section{b. Understanding Community Involvement}

Community involvement is the active participation of the community in the decisionmaking process about what will be done and how it works, community involvement in carrying out programs and decisions that have been determined through the contribution of resources or cooperation in an organization, community involvement enjoys the benefits of development as well as in the evaluation of program implementation.. [9]

a) Aspects of Community Involvement Level

[9] Divide community involvement into several aspects, namely:

\section{Decision Making}

At this stage that is realized by the participation of the community in the implementation of the meeting. This decision-making stage includes the planning and implementation of a program.

\section{Implementation}

At this stage it is an important stage in the development of a program, because thecore of development is in its implementation. The real form of involvement at this stage is divided into three, namely about involvement in the form of contributions in the form of thoughts, donations in the form of materials, and actions as a member of the project.

\section{Evaluation}

At this stage is considered important because community involvement at this stage is feedback that can provide input for improvement for the implementation of the next program.

4. Enjoy the Results

Which is used as an indicator of the success of community involvement in the planning and implementation stage of the project. In addition, seeing the position of the community as a subject of development, the greater the benefits of the project are felt, so the project succeeds precisely on target.

\section{RESEARCH METHODS}

In this study, the design used is quantitative research. Quantitative research is a research method used to examine a particular population or sample, in this study data collection using research instruments, analysis and quantitative or statistical, which aims to test established hypotheses. A research variable is the attribute or nature or value of another person, object or activity that has certain variations set by the researcher to be studied and after that a conclusion is drawn. Bound variables are variables that are affected or that become a result, because of the existence of free variables. The bound variable in this study is the Success Rate of Implementation of Corporate Social Responsibility (CSR)Programs. A free variable is a 
variable that affects or is the cause of its change or the onset of bound variables. The free variable in the study is the Level of Community Involvement. [10]

\section{RESULT AND DISCUSSION}

\section{Results of Measurement of Validity and Reliability}

Table 1 Blue print Community Involvement questionnaire after trial

\begin{tabular}{|c|c|c|c|c|c|c|c|c|c|}
\hline \multirow{3}{*}{ o. } & \multirow[t]{3}{*}{ Aspects } & \multirow[t]{3}{*}{ Indica } & \multicolumn{2}{|c|}{ Valid Item } & \multicolumn{2}{|c|}{ Fall Item } & \multicolumn{2}{|l|}{$\mathrm{J}$} & \multirow{3}{*}{$\begin{array}{l}\mathrm{T} \\
\mathrm{It}\end{array}$} \\
\hline & & & & & & & \multirow{2}{*}{$\begin{array}{l}\mathrm{ml} \\
\text { item }\end{array}$} & \multirow{2}{*}{$\begin{array}{l}\text { otal } \\
\text { ems }^{\text {It }}\end{array}$} & \\
\hline & & & $\begin{array}{ll} & \text { F } \\
\text { av } & \end{array}$ & fav & $\begin{array}{ll} & \text { F } \\
\text { av } & \end{array}$ & fav & & & \\
\hline \multirow[t]{2}{*}{$\begin{array}{l}1 \\
.\end{array}$} & \multirow[t]{2}{*}{ Decision } & $\begin{array}{l}\quad \text { Atten } \\
\mathrm{d} \text { a meeting } \\
\text { for the } \\
\text { implement } \\
\text { ation of the } \\
\text { program }\end{array}$ & 1 & 3 & - & - & 2 & 2 & \\
\hline & & $\begin{array}{l}\text { Partic } \\
\text { ipate in } \\
\text { program } \\
\text { planning }\end{array}$ & 2 & 4 & - & - & 2 & 2 & \\
\hline \multirow[t]{3}{*}{3} & \multirow[t]{3}{*}{$\begin{array}{l}\text { Impleme } \\
\text { ntation }\end{array}$} & $\begin{array}{l}\text { Contr } \\
\text { ibute } \\
\text { thought to } \\
\text { the } \\
\text { program }\end{array}$ & 8 & 6 & - & - & 2 & 2 & \\
\hline & & \begin{tabular}{l}
\multicolumn{2}{r}{ Actio } \\
ns as a \\
member
\end{tabular} & - & 7 & 5 & - & 2 & 1 & \\
\hline & & $\begin{array}{l}\text { Donat } \\
\mathrm{e} \text { in the } \\
\text { form of } \\
\text { material }\end{array}$ & - & - & 1 & 12 & 2 & - & \\
\hline 3 & $\begin{array}{ll} & \text { Evaluatio } \\
\mathrm{n} & \end{array}$ & $\begin{array}{l}\text { Give } \\
\text { feedback } \\
\text { on the } \\
\text { program }\end{array}$ & $0,15^{1}$ & 13 & - & 9 & 4 & 3 & \\
\hline 4 & $\begin{array}{l}\text { Enjoying } \\
\text { results }\end{array}$ & $\begin{array}{l}\text { Feel } \\
\text { the benefits } \\
\text { gained }\end{array}$ & $6,17^{1}$ &, $18^{14}$ & - & - & 4 & 4 & \\
\hline
\end{tabular}

8

Based on table 1 of 18 items on the community involvement variable there are 14 valid items and 4 items that fall. The item is considered valid because it meets a correlation coefficient of at least 0.30 . Valid items are addressed from $r$ values that range from $0.30-0.80$. While items that are considered valid and fall on research instruments. 
UMGCINMATIC : $1^{\text {st }}$ Rethinking Education during Covid-19 Era: Challange and Innovation Volume 1 No 2

Table 2 Blue print questionnaire Success of Program Implementation after trial

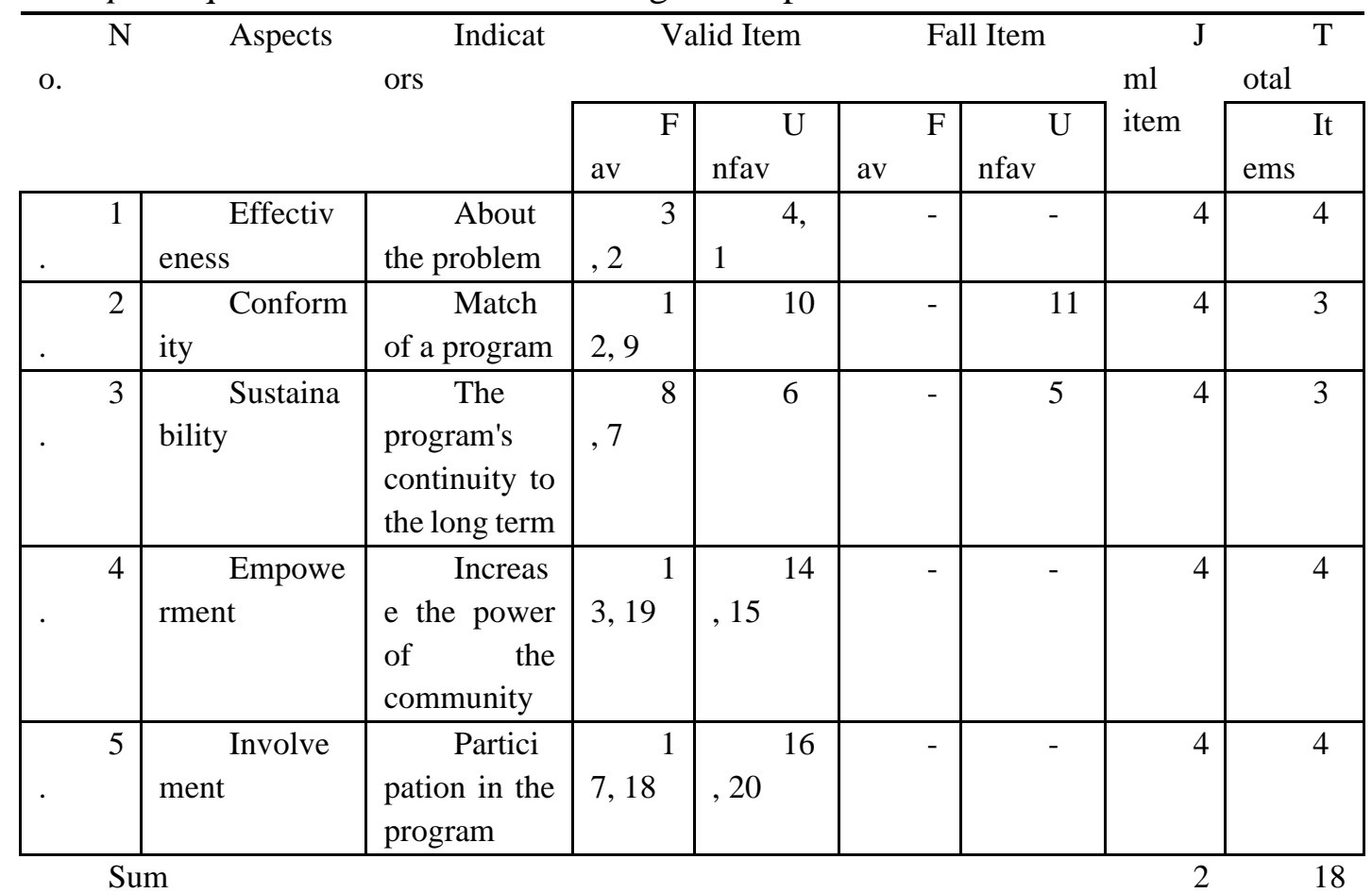

0

Based on a table of 2 of the 20 items on the success variables of program implementation there are 18 valid items and 2 items that fall. The item is considered valid because it meets a correlation coefficient of at least 0.30 . Valid items are intended from $r$ values that range from $0.30-0.90$.

Table 3 Test reliability of Community Involvement Instruments

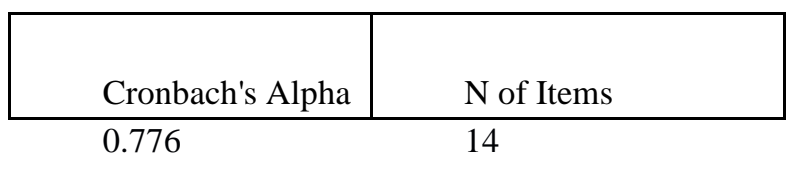

S umber: SPSS 25.0 for windows

Table 3 shows that the results of the analysis on community involvement instruments show reliability results of 0.776 which means reliable. A scale or research instrument considered reliable should have at least a reliable reliable value of 0.70 or more. [11]

Table 4 Reliability Test instruments for successful implementation of CSR programs

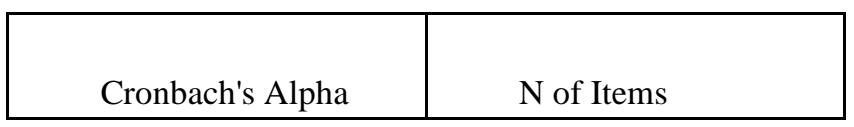


0.831

18

Source: SPSS 25.0 for windows

In table 4 shows that the results of the analysis on the instrument of program implementation success show reliability results of 0.831 which means reliable. According to Azwar (2017: 98) a scale or research instrument considered reliable should have at least a reliable reliable value of 0.70 or more. [11]

\section{Assumption Test Results}

Normality and Linearity Test

Table 5 Normality Test Results

\begin{tabular}{|c|c|c|c|}
\hline Variable & $\mathbf{N}$ & $\begin{array}{l}\text { Sig } \\
\text { le. }\end{array}$ & Information \\
\hline Community involvement & 79 & 0,200 & Usual \\
\hline $\begin{array}{l}\text { Successful implementation of the } \\
\text { program }\end{array}$ & 79 & 0,068 & Usual \\
\hline
\end{tabular}

Source: SPSS 25.0 for windows

correlation coefficient of at least 0.30 . Valid items are intended from $r$ values that range from $0.30-0.90$.

Table 3 Test reliability of Community Involvement Instruments

\begin{tabular}{|l|l|}
\hline Cronbach's Alpha & N of Items \\
\hline 0.776 & 14 \\
\hline
\end{tabular}

S umber: SPSS 25.0 for windows

Table 3 shows that the results of the analysis on community involvement instruments show reliability results of 0.776 which means reliable. A scale or research instrument considered reliable should have at least a reliable reliable value of 0.70 or more. [11]

Table 4 Reliability Test instruments for successful implementation of CSR programs

\begin{tabular}{|l|l|}
\hline & \\
Cronbach's Alpha & N of Items \\
\hline 0.831 & 18 \\
\hline
\end{tabular}

Source: SPSS 25.0 for windows

In table 4 shows that the results of the analysis on the instrument of program implementation success show reliability results of 0.831 which means reliable. According to Azwar (2017: 98) a scale or research instrument considered reliable should have at least a reliable reliable value of 
0.70 or more. [11]

Assumption Test Results

Normality and Linearity Test

Table 5 Normality Test Results

\begin{tabular}{|l|r|r|r|}
\hline Variable & N $\begin{array}{c}\text { Sig } \\
\text { value. }\end{array}$ & Information \\
\hline Community involvement & 79 & 0,200 & Usual \\
\hline $\begin{array}{c}\text { Successful implementation of the } \\
\text { program }\end{array}$ & 79 & 0,068 & Usual \\
\hline
\end{tabular}

Source: SPSS 25.0 for windows

Based on the results of normality testing in Table 5,Community Involvement obtained results of 0,200 \&gt; 0.05 and Successful Implementation of Program 0.068 \&gt; 0.05 Then it can be concluded that the residual value of community Involvement variables and the successfulimplementation of normal distributed programs. [12]

Table 6 Linearity Test Results

\begin{tabular}{cccll}
\hline Variable & & $\mathbf{N}$ & Linearity & Information \\
\hline $\begin{array}{c}\text { Community } \\
\text { involvement }\end{array}$ and & 79 & 0,121 & Linear \\
successful implementation of the program & & & \\
\hline
\end{tabular}

Source: SPSS 25.0 for windows

Based on Table 6 data of linearity test results it can be known that the value of significance in linearity of 0.121 greater than 0.05 means that there is a significant linear relationship between the variables of program implementation success and community involvement. [12]

\section{Analysis of Research Results Data}

Table 7 Simple Linear Regression Test Results(Summary Model Table)

\begin{tabular}{cccc}
\hline Variable & $\mathbf{N}$ & $\mathbf{R}$ & $\begin{array}{c}\mathbf{R} \\
\text { Square }\end{array}$ \\
\hline $\begin{array}{c}\text { Community Involvement and Successful } \\
\text { Implementation of the Program }\end{array}$ & 79 & 0,452 & 0,204 \\
\hline
\end{tabular}

Source: SPSS 25.0 for windows

The result of data analysis from the linear regression technique from the summary model table in table 7 , the value $R$ shows the correlation coefficient number of 0.452 . The results of data analysis from linear regression techniques from summary model tables show that the value of $\mathrm{R}^{2}$ ( $R$ Square) is 0.204 or $20.4 \%$.

Table 8 Simple Linear Regression Test Results(Anova Table)

\begin{tabular}{ccclll}
\hline Variable & & & N & F & Sig \\
\hline $\begin{array}{c}\text { Community } \begin{array}{c}\text { Involvement } \\
\text { Implementation of the Program }\end{array} \\
\text { and }\end{array}$ & Successful & 79 & 19.751 & 0,000 \\
\hline
\end{tabular}


Source: SPSS 25.0 for windows

Table 8 looks at the regression equation model used to predict variable Y. The result of the anova or $F$ test table obtained a calculated $F$ value of 19.751 with a probability of 0.000 that is much smaller than 0.05 . This means that the value of the coefficient of determination $\mathrm{R}^{2}$ is not equal to zero or significant. It can then be concluded that variable $\mathrm{X}$ (community engagement) can significantly predict variable $Y$ (successful implementation of the program).

Table 9 Simple Linear Regression Test Results (Table coefficients))

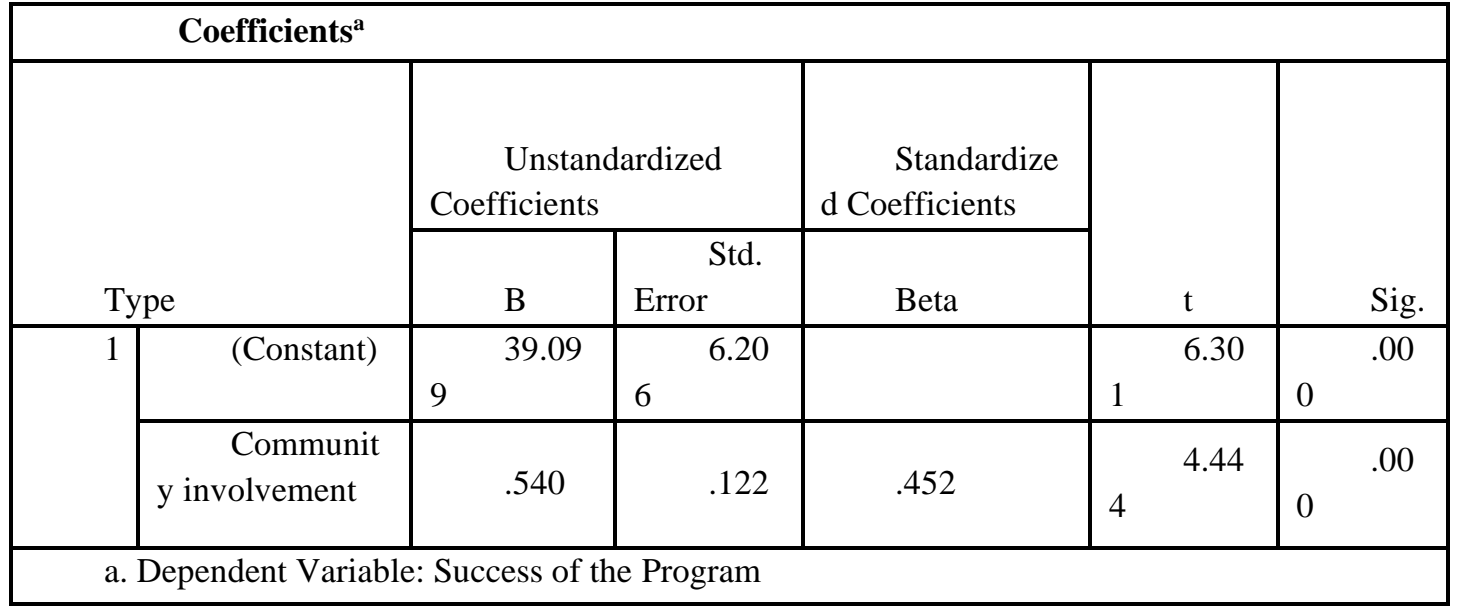

Source: SPSS 25.0 for windows

Table Coefficients are used to determine the regression coefficient and the alignment of variable $\mathrm{X}$ to variable $\mathrm{Y}$. In the coefficients table it is known that the independent variable (community involvement) included in the model turns out to be significant, this is seen from the probability of its significance well below 0.05 . So it can be concluded that the success variable of the program execution is influenced by the variable of community involvement with the mathematical equation $y=39.099+0.540 \mathrm{x}$. The regression coefficient of community involvement of 0.540 states that the higher the level of community involvement, the higher the success rate of program implementation.

Table 9 Simple Linear Regression Test Results (Table coefficients))

\begin{tabular}{|c|c|c|c|c|c|c|}
\hline \multicolumn{7}{|c|}{ Coefficients $\mathrm{s}^{\mathrm{a}}$} \\
\hline \multirow{2}{*}{\multicolumn{2}{|c|}{ Type }} & \multicolumn{2}{|c|}{$\begin{array}{l}\text { Unstandardized } \\
\text { Coefficients }\end{array}$} & \multirow{2}{*}{$\begin{array}{c}\begin{array}{c}\text { Standardize } \\
\mathrm{d} \text { Coefficients }\end{array} \\
\text { Beta }\end{array}$} & \multirow[b]{2}{*}{$\mathrm{t}$} & \multirow[b]{2}{*}{ Sig. } \\
\hline & & B & $\begin{array}{l}\text { Std. } \\
\text { Error }\end{array}$ & & & \\
\hline 1 & (Constant) & 39.09 & $\begin{array}{ll} & 6.20 \\
6 & \end{array}$ & & $\begin{array}{ll} & 6.30 \\
1 & \end{array}$ & .00 \\
\hline & $\begin{array}{l}\text { Communit } \\
\text { y involvement }\end{array}$ & .540 & .122 & .452 & $4 \quad 4.44$ & $\begin{array}{ll} & .00 \\
0 & \end{array}$ \\
\hline
\end{tabular}

Source: SPSS 25.0 for windows

Table Coefficients are used to determine the regression coefficient and the alignment of 
variable $\mathrm{X}$ to variable $\mathrm{Y}$. In the coefficients table it is known that the independent variable (community involvement) included in the model turns out to be significant, this is seen from the probability of its significance well below 0.05 . So it can be concluded that the success variable of the program execution is influenced by the variable of community involvement with the mathematical equation $y=39.099+0.540 \mathrm{x}$. The regression coefficient of community involvement of 0.540 states that the higher the level of community involvement, the higher the success rate of program implementation.

implementation, while the remaining $79.6 \%$ is influenced by other dimensions outside the study. It agrees like suggest that the efficacy of public relations programmes be evaluated using five relationship dimensions: trust, openness, involvement, investment, and commitment. This means that the sustainability of public relations programs is evaluated using five dimensions of relationships: trust, openness, engagement, investment, and commitment. Other dimensions that affect people's success rates besides engagement are openness, investment, and commitment.

\section{CONCLUSION}

Based on research conducted by researchers on the influence of community involvement levels on the success rate of csr program implementation (Corporate Social Responsibilty) in the indro village environment, it can be concluded that the level of community involvement has a significant influence on the success rate of csr program implementation(Corporate Social Responsibilty). ) in the indro village environment with the results of hypothetical tests that show a significance value of 0.000 , this value is smaller than the alpha value of 0.05 so that Ho is rejected and $\mathrm{Ha}$ is accepted so that it can be concluded that there is a significant influence between the involvement of the community with the success rate of the implementation of CSR programs in the Indro village environment.

The percentage of the influence of the level of community involvement on the success rate of implementing CSR (Corporate Social Responsibilty) programs in the Indro village environment obtained a coefficient of determination $(R)$ of $r=0.4522=0.204$. That is, $R=0.204$ means $R=$ $20.4 \%$ means that there is an influence of the level of community involvement of $84.8 \%$ on the success rate of CSR program implementation, while the remaining $79.6 \%$ is influenced by other dimensions outside the study. These results indicate that when the community has a high involvement, it will increase the success rate of implementing a high CSR program. Conversely, when the community has low involvement, the success rate of implementing CSR (Corporate Social Responsibility) programs is low.

\section{REFERENCES}

Astari, H. (2012). Pemanfaatan Corporate Social Responsibility (CSR) Bagi Peningkatan Kualitas Hidup Manusia Indonesia. Aspirasi, 3(2).

Azwar, S. (2016). Reliabilitas dan Validitas. Yogyakarta: Pustaka Belajar.

Choen, J., \& Uphoff, N. (1980). Participation's Place In Rural Development: Seeking Clarity Through Specificity. World Development, 8, 213-235Lindawati, A. S., \& Puspita, M. E. (2015). Corporate Social Responsibility : Implikasi Stakeholder dan Legitimacy Gap 
Dalam Peningkatan Kinerja Perusahaan. Akuntansi Multiparadigma, 6(1), 1-174.

Gunawan, C. (2018). Mahir Menguasa bi SPSS. Yogyakarta: CV Budi Utama.

Ghozali, I. (2011). Ekonometrika. Semarang: Badan Penerbit Universitas Diponegoro.

Hadi, N. (2011). Corporate Social Responsibility. Yogyakarta: Graha Ilmu.

Irwanto, A. (2014). Implementasi Tanggung Jawab Sosial PT Petrokimia Gresik Pada Masyarakat Lokal. Akuntansi Multiparadigma, 5(3).

Muhdar, Jamaludin, \& Irwansyah. (2014). Partisipasi Masyarakat Dalam Program Corporate Social Responsibility PT. Arutmin Nort Pulau Laut Coal Terminal Kotabaru. Bisnis dan Pembangunan, l(1).

Nurbaiti, S. R., \& Bambang, A. N. (2017). Faktor-Faktor Yang Mempengaruhi Partisipasi Masyarakat Dalam Pelaksanaan Program Corporate Social Responsibility (CSR). Proceeding Biology Education Conference, 14(1), 224-228.

Prayogo, D., \& Hilarius, Y. (2012). Efektifitas Program CSR/CD dalam Pengentasan Kemiskinan: Studi Peran Perusahaan Geoternal di Jawa Barat. Sosiologi Masyarakat, 17(1)..

Sugiyono. (2016). Metode Penelitian Kuantitatif. Bandung: Alfabeta.

Suparman. (2013). Corporate Social Responsibility : Bentuk Tanggung Jawab Sosial dan Kepedulian Perusahaan dengan Mayarakat. Interaksi, II(2), 69-81. 